\title{
The assessment of the toxicity of nanocomplexes containing gadolinium orthovanadate nanoparticles and cholesterol
}

\author{
Goltsev A. ${ }^{1}$, Bondarovych M. ${ }^{1}$, Babenko N. ${ }^{1}$, Gaevska Yu. ${ }^{1}$ Ostankova L. ${ }^{1}$, Ostankov M. ${ }^{1}$, Volkova N. ${ }^{1}$, Klochkov V. \\ ${ }^{1}$ Institute for Problems of Cryobiology and Cryomedicine, National Academy of Sciences of Ukraine, Kharkiv, Ukraine \\ ${ }^{2}$ Institute for Scintillation Materials, National Academy of Sciences of Ukraine, Kharkiv, Ukraine \\ Corresponding author’s e-mail: cryopato@gmail.com
}

\section{ABSTRACT}

Nanocomplexes (NCs) synthesized at the Institute for Scintillation Materials of the National Academy of Sciences of Ukraine, consisting of nanoparticles (NPs) of gadolinium orthovanadate and cholesterol, are promising compounds that can be used as probes and fluorescent labels for tumor cells or experimental oncopathology treatment. However, the biosafety of such substances remains unclear.

The PURPOSE of the study was to evaluate the acute toxic effect of nanocomplexes on the healthy mice.

MATERIALS AND METHODS. Nanocomplexes containing nanoparticles of GdYVO4:Eu ${ }^{3+}$ and cholesterol in $5 \%$ glucose solution were administered to BALB/c mice once intraperitoneally in volumes of $0.1 \mathrm{~mL}, 0.5 \mathrm{~mL}, 1 \mathrm{~mL}, 2 \mathrm{~mL}$, which corresponds to $5.9-6,5 \mathrm{mg}, 29.5-32.5 \mathrm{mg}$, $59.1-65.0 \mathrm{mg}, 118.2-130.0 \mathrm{mg} / \mathrm{kg}$ body weight. Control animals were injected with the same volumes of $5 \%$ glucose solution. On the $14^{\text {th }}$ day, the morphological characteristics of organs, the number of $C D 34^{+} C D 38^{-}$cells among bone marrow total nucleated cells, the activity of gammaglutamyl transferase (GGT) and glucose-6-phosphate dehydrogenase (G6PD) in liver homogenates were determined.

RESULTS. With the administration of NPS at a dose of less than $118.2 \mathrm{mg} / \mathrm{kg}$ body weight, no fatalities and symptoms of intoxication were showed, but there was a dose-dependent increase in the content of GGT in the liver of experimental animals. The use of NPs at a dose of 118.2$130.0 \mathrm{mg} / \mathrm{kg}$ body weight resulted in the death of $50 \%$ of the animals on the $3^{\text {rd }}$ day. In this group, on the $14^{\text {th }}$ day, there were neoplasms in the spleen of one of the surviving animals, a decrease in the number of bone marrow total nucleated cell on the background of increased hematopoietic stem cells with CD34+CD38- phenotype, necrotic and dystrophic changes in the liver, and decreased activity of the G6PD enzyme.

CONCLUSIONS. The potential median lethal dose of gadolinium orthovanadate nanoparticles and cholesterol in nanocomplexes was determined, which was $118.2-130.0 \mathrm{mg} / \mathrm{kg}$ animal body weight, which allows to classify them as low-toxic substances.

KEY WORDS: nanoparticles; nanocomplexes; gadolinium orthovanadate; median lethal dose

The synthesis of brand new materials in the form of nanoparticles (NPs) and their introduction into medicine and pharmacy is one of the most promising scientific areas [1]. The transition to nanosized substances is accompanied by the acquisition of completely new structural (temperature, magnetic, electrical, etc.) characteristics [2]. The predominance of wave properties in nanomaterials over corpuscular ones causes a significant change in their physicochemical properties, which can be used in biological, biochemical and pharmacological studies [1]. In NPs, most atoms are on the surface, the electrons of the atoms are compacted in a smaller than usual space, which significantly changes their properties [3]. NPs can penetrate directly through the skin, respiratory and digestive organs, cell membranes pores or by cellular transport mechanisms and are distributed throughout the body [4]. Due to their nanosize, NPs have the ability to control, restore, reconstruct and regulate biosystems at the molecular level, as well as exhibit unique photoluminescent properties due to their high photostability over time, significant Stokes shift, no flicker effect, stability of narrow luminescence bands, that provides the prospect of their use as fluorescent labels and probes in solving a number of problems associated with the molecular diagnosis of cancer [5].

The growing use of NPs requires scientists to pay more attention to studying the possibilities of negative impact on the human body during their production and subsequent use. Regardless of the pathways of NPs in the body, they are usually distributed with blood throughout the body and accumulate in the bone marrow, central and peripheral nervous 
systems, organs of the gastrointestinal tract, lungs, liver, kidneys, and lymph nodes [6]. In this case, depending on the size and its chemical activity, NPs can cause damage to cell membranes of all tissues and organs by forming stable compounds with proteins causing changes in their functional properties, including by the induction of injury of the nucleus, mitochondria and other organelles, which even leads to cell death [6].

Rare earth metals have been of great interest to researchers in the field of biomedicine in recent decades due to their unique physicochemical properties $[7,8]$. Rare earth metals in the form of nanomaterials can be used in biomedicine, in particular to obtain multimodal images, biodetection, "targeted" delivery of substances, biolabelling, etc. [7-9].

Vanadium is a transition metal, the content of which in the earth's crust is $1.9 \cdot 10^{-2} \mathrm{wt} \%$, but it does not occur in nature in free form, and exists only in the form of compounds. Since the sizes of vanadium atoms and the most common metals ( $\mathrm{Fe}, \mathrm{Ti}, \mathrm{Mn}$ ), as well as the sizes of vanadate and phosphate ions are close, vanadium is a part of many minerals and complex ores of other metals (magnetite, titanium-magnetite, sedimentary iron, phosphorites, apatites etc.) [10]. Sufficient experimental data have been accumulated on the ability of vanadium to modulate the activity of a number of enzymes, including protein tyrosine phosphatase, inhibition of fatty acid synthesis, inhibition of cholesterol synthesis, reduction of coenzyme $A$ and coenzyme $Q$, stimulation of glucose utilization $[10,11]$. This was a prerequisite for the use of vanadium compounds in the experimental treatment of diabetes [10]. The addition of vanadium compounds to the diet of animals with induced or genetically determined type 2 diabetes mellitus has been shown to normalize blood glucose and insulin levels and to promote pancreatic $\beta$-cell regeneration [12]. However, none of the vanadium compounds has been shown to be effective in long-term use in people with diabetes, although bis-(2-ethyl-3-hydroxy4-pyronato)-oxovanadium (IV) is already undergoing phase II clinical trials as a therapeutic agent [13].

This caution in the use of vanadium compounds in the therapy of diabetes is partly due to its ability to induce Fenton reactions with the formation of reactive oxygen species (ROS). Excessive production of ROS can cause the development of oxidative stress, which leads to the modification of proteins with the formation of protein radicals, the initiation of lipid peroxidation, DNA breaks, the modulation of gene expression by redox modulation of transcription factors with the subsequent development of the inflammation, genotoxic effects and even cell death [14].

This formed the basis for the idea of using vanadium compounds as antitumor agents. For the first time Köpf-Maier P. et al. in 1986 reported the effectiveness of the use of vanadocene in the treatment of Ehrlich ascites carcinoma [15]. Subsequent studies have shown that the antiproliferative potential of vanadium compounds can be realized by accumulation in nuclear heterochromatin [16] with temporary inhibition of mitosis, accumulation of cells in the late S- and G2-phase [17], and with the induction of mitotic aberrations [18]. Vanadium compounds can cause selective oxidation of pyrimidine bases, which prevents complementary DNA twisting [19]. Tumor cells, which are characterized by disorders of the DNA repair system, are particularly prone to this.

Another probable mechanism of antitumor action of vanadium compounds is the induction of oxidative imbalance in the cell due to the generation of ROS [20], which leads to the release of cytochrome $C$ and the induction of apoptosis [21]. This is consistent with the data of Goltsev A. et al., which demonstrating that the effective implementation of the antitumor effect of gadolinium orthovanadate NPs involves their penetration and accumulation within cells, mitochondrial dysfunction with subsequent induction of apoptotic and necrotic changes in tumor cells [9].

It is established that the decrease in mitochondrial potential, which indicates the impairment of mitochondrial function, depends on the size and shape of gadolinium orthovanadate NPs [7]. The authors showed that in contrast to spindle-shaped $\mathrm{GdVO}_{4}: \mathrm{Eu}^{3+}$ and shear-like $\mathrm{LaVO}_{4}: \mathrm{Eu}^{3+}$ spherical NPs of $\mathrm{GdYVO}_{4}$ :Eu ${ }^{3+}$ showed an earlier (after 1 hour of incubation) and more pronounced decrease in mitochondrial potential of freshly isolated hepatocytes. This effect can be explained by the increased re- activity of spherical NPs due to the peculiarities of their penetration into cells. It is noteworthy that cells, due to the activation of the antioxidant system, were able to partially neutralize the toxic effects of NPs, but as it turned out, these resources were insufficient to protect from oxidative stress caused by prolonged (within 24 hours) exposure to NPs of all orthovanadate forms [7].

The improvement of methods of oncological disease treatment can be achieved by the modification of NPs, in particular, the creation of nanoemulsions on their basis. In this regard, the complexation of NPs with cholesterol and, thus, the creation of nanocomplexes (NCs) is promising [22]. NCs are kinetically stable dispersion that are resistant to segregation for several months [22]. It is known that cancer cells, having increased metabolic activity, are able to selectively capture cholesterol from the environment [23]. Therefore, the addition of cholesterol to NPs is a prerequisite for the successful targeted delivery of NCs to tumor sites, in particular Ehrlich adenocarcinoma (EAC) cells. NPs containing spherical NPs $(1.3 \mathrm{~g} / \mathrm{L})$ and cholesterol $(0.55 \mathrm{~g} / \mathrm{L})$ have been shown to be able to bind only to certain subpopulations of EAC with the signs of cancer stem cells and inhibit their activity [24]. This dose of NCs can be considered as conditionally therapeutic. However, the possibility of toxic influence on the function of normal cells in case of their application in vivo is not excluded.

Thus, the question of the nonspecific effect of vanadates on various cells remains unclear, which can cause nanotoxicity to a number of organs and tissues that are capable of accumulating vanadium compounds. This necessitates research to determine the impact of NCs on the performance of healthy animals, which was the purpose of this study.

\section{MATERIALS AND METHODS}

The study was performed in 8-month-old healthy female BALB/c mice weighing 20-22 g, which were kept in standard vivarium conditions of the Institute for Problems of Cryobiology and Cryomedicine of the National Academy of Sciences of Ukraine. All animal manipulations were approved by the Bioethics Committee and performed in accordance with the "General Principles of Experiments in Animals", approved by the First National Congress on Bioethics (Kyiv, 2004) and in accordance with the provisions of "European Convention for the Protection of Vertebrate Animals Used for Experimental and Other Scientific Purposes" (Strasbourg, 1986).

Nanocomplexes (NCs) containing spherical gadolinium-yttrium orthovanadate $\mathrm{GdYVO}_{4}: \mathrm{Eu}^{3+}(1.3 \mathrm{~g} / \mathrm{L})$ and cholesterol $(0.55 \mathrm{~g} / \mathrm{L})$ (Acros Organics, Belgium) were synthesized by the Institute for Scintillation Materials of the National Academy of Sciences of Ukraine (Kharkiv) [22]. To obtain NCs solutions, cholesterol was dissolved in ethanol and added to the mixture a sterile aqueous solution of NPs the size of 2-3 nm (sterilization in ampoules at $120{ }^{\circ} \mathrm{C}$ ), followed by vacuum evaporation of alcohol and adding sterile isotonic $5 \%$ glucose solution (Infusion, Ukraine) [22].

Acute toxicity was induced by a single intra-abdominal injection of different doses of NCs in the first part of the day. The choice of administered NCs concentrations was determined by the results of previous studies [24], which allow us to consider a dose of $0.13 \mathrm{mg}$ of NPs per animal in nanocomplexes as a conditionally therapeutic one in the treatment of experimental oncopathology. According to the recommendations [25] the following experimental groups were formed (in each group of ten animals):

- Group 1 - injection of $0.1 \mathrm{~mL}$ of NCs $(0.13 \mathrm{mg}$ of NPs per mouse; $5.9-6.5 \mathrm{mg} / \mathrm{kg}$ of the body weight);

- Group 2 - injection of $0.5 \mathrm{~mL}$ of NCs $(0.65 \mathrm{mg}$ of NPs per mouse; $29.5-32.5 \mathrm{mg} / \mathrm{kg}$ );

- $\quad$ Group 3 - injection of $1 \mathrm{~mL}$ of NCs (1.3 mg of NPs per mouse; $59.1-65.0 \mathrm{mg} / \mathrm{kg}$ );

- Group 4 - injection of $2 \mathrm{~mL}$ of NCs (2.6 mg of NPs per mouse; $118.2-130 \mathrm{mg} / \mathrm{kg}$ ).

Animals of control groups $(n=10)$ were injected intraperitoneally with the solution of $5 \%$ glucose (Infusion, Ukraine) $0.1 ; 0.5$; 1 ; and $2 \mathrm{~mL}$ per 


\begin{tabular}{|c|c|c|c|c|c|c|}
\hline \multirow{3}{*}{ GROUP } & \multirow{3}{*}{ THE DOSE OF INJECTED SUBSTANCE } & \multicolumn{5}{|c|}{ PERCENTAGE OF SURVIVING ANIMALS, \% } \\
\hline & & \multicolumn{5}{|c|}{ DAY } \\
\hline & & $\mathbf{0}$ & 3 & 7 & 10 & 14 \\
\hline Group 1 & 5.9-6.5 mg/kg NPs (0.1 mL NCs) & 100 & 100 & 100 & 100 & 100 \\
\hline Group 2 & 29.5-32.5 mg/kg NPs (0.5 mL) & 100 & 100 & 100 & 100 & 100 \\
\hline Group 3 & $59.1-65.0 \mathrm{mg} / \mathrm{kg} \mathrm{NPs}(1 \mathrm{~mL})$ & 100 & 100 & 100 & 100 & 100 \\
\hline Group 4 & $118.2-130.0 \mathrm{mg} / \mathrm{kg} \mathrm{NPs}(2 \mathrm{~mL})$ & 100 & 50 & 30 & 20 & 20 \\
\hline Control 1 & $0.1 \mathrm{~mL} 5 \%$ glucose & 100 & 100 & 100 & 100 & 100 \\
\hline Control 2 & $0.5 \mathrm{~mL} 5 \%$ glucose & 100 & 100 & 100 & 100 & 100 \\
\hline Control 3 & $1 \mathrm{~mL} 5 \%$ glucose & 100 & 100 & 100 & 100 & 100 \\
\hline Control 4 & $2 \mathrm{~mL} 5 \%$ glucose & 100 & 90 & 90 & 90 & 90 \\
\hline Intact & - & 100 & 100 & 100 & 100 & 100 \\
\hline
\end{tabular}

Table 1. The number of animals that survived up to 14 days at the induction of acute toxicity by administering different concentrations of NPs in nanocomlexes.

\begin{tabular}{|c|c|c|c|c|}
\hline \multirow{2}{*}{ GROUP } & \multirow{2}{*}{ THE DOSE OF INJECTED SUBSTANCE } & \multicolumn{2}{|c|}{ THE TERM OF STUDY, DAY } & \multirow{2}{*}{ INCREASE, G } \\
\hline & & $\mathbf{0}$ & 14 & \\
\hline Group 1 & 5.9-6.5 mg/kg NPs (0.1 mL NCs) & $\begin{array}{c}22.0 \\
{[20.6 ; 22.5]}\end{array}$ & $\begin{array}{c}23.0 \\
{[21.5 ; 23.5]}\end{array}$ & $\begin{array}{c}1.1 \\
{[0.8 ; 1.2]^{\star}}\end{array}$ \\
\hline Group 2 & 29.5-32.5 mg/kg NPs (0.5 mL) & $\begin{array}{c}19.9 \\
{[19.0 ; 21.2]}\end{array}$ & $\begin{array}{c}21.2 \\
{[20.5 ; 22.9]}\end{array}$ & $\begin{array}{c}1.3 \\
{[1.3 ; 1.5]^{\star}}\end{array}$ \\
\hline Group 3 & 59.1-65.0 mg/kg NPs (1 mL) & $\begin{array}{c}22.4 \\
{[20.6 ; 22.7]}\end{array}$ & $\begin{array}{c}22.5 \\
{[20.7 ; 22.9]}\end{array}$ & $\begin{array}{c}0.1 \\
{[0.1 ; 0.1]^{\star} \#}\end{array}$ \\
\hline Group 4 & 118.2-130.0 mg/kg NPs (2 mL) & $\begin{array}{c}19.9 \\
{[19.5 ; 20.9]}\end{array}$ & $\begin{array}{c}18.2 \\
{[17.6} \\
19.0]^{\star} \#\end{array}$ & $\begin{array}{c}1.9 \\
{[-1.9 ;-} \\
2.2]^{\star} \#\end{array}$ \\
\hline Control 1 & $0.1 \mathrm{~mL} 5 \%$ glucose & $\begin{array}{c}21.5 \\
{[19.5 ; 22.4]}\end{array}$ & $\begin{array}{c}22.9 \\
{[21.7 ; 23.8]}\end{array}$ & $\begin{array}{c}1.2 \\
{[0.6 ; 2.3]}\end{array}$ \\
\hline Control 2 & $0.5 \mathrm{~mL} 5 \%$ glucose & $\begin{array}{c}20.0 \\
{[19.0 ; 20.8]}\end{array}$ & $\begin{array}{c}21.7 \\
{[20.7 ; 22.0]}\end{array}$ & $\begin{array}{c}1.4 \\
{[0.8 ; 1.6]}\end{array}$ \\
\hline Control 3 & $1 \mathrm{~mL} 5 \%$ glucose & $\begin{array}{c}20.7 \\
{[18.9 ; 22.4]}\end{array}$ & $\begin{array}{c}23.9 \\
{[22.8 ; 24.8]}\end{array}$ & $\begin{array}{c}2.7 \\
{[2.5 ; 3.3]}\end{array}$ \\
\hline Control 4 & $2 \mathrm{~mL} 5 \%$ glucose & $\begin{array}{c}20.7 \\
{[19.7 ; 21.5]}\end{array}$ & $\begin{array}{c}22.9 \\
{[21.7 ; 23.6]}\end{array}$ & $\begin{array}{c}2.3 \\
{[2.0 ; 2.6]}\end{array}$ \\
\hline Intact & - & $\begin{array}{c}21.8 \\
{[20.9 ; 22.6]}\end{array}$ & $\begin{array}{c}23.8 \\
{[22.8 ; 24.6]}\end{array}$ & $\begin{array}{c}2.0 \\
{[1.8 ; 2.2]}\end{array}$ \\
\hline
\end{tabular}

Table 2. The dynamics of body weight of mice on the $14^{\text {th }}$ day after the induction of acute toxicity by injection of different concentrations of NPs in nanocomplexes, Me $\left[25^{\text {th }} ; 75^{\text {th }}\right.$ percentiles].

Notes: * ${ }^{*} p<0.005$ compared to intact animals; \# - compared to control of the corresponding group; according to the Bonferroni-corrected Mann-Whitney U-test. mouse, respectively. NCs and glucose solutions were injected at a fixed time of a day to prevent errors associated with the circadian rhythms of the animals. BALB/s mice $(n=10)$ were intact controls without any injections.

According to the principles of acute toxicity assessment [25], we evaluated the general condition of animals, their behavior, food and water intake, symptoms of intoxication, change in body weight, percentage of dead animals at different times during the experiment: in the first 30 minutes after administration of NPs and then daily for 14 days. The degree of toxicity of NPs in nanocomlexes was determined by the median lethal dose $\left(\mathrm{LD}_{50}\right)$ in accordance with the classification of substances by toxicity [26].

On the $14^{\text {th }}$ day, the animals were euthanized under ether anesthesia and spleen, inguinal lymph nodes, lungs, kidneys and liver were isolated. Organs were weighed with subsequent calculation of organ mass indices according to the formula: (organ weight $(\mathrm{m}) /$ body weight $(\mathrm{M})$ ) • $100 \%$ [27]. The number of leukocytes and erythrocytes were counted using a Goryaev's chamber. To obtain bone marrow (BM) cell suspension, the isolated femurs were cleaned with a scalpel from muscle and connective tissue, the epiphyses were cut with scissors and BM cells were washed using a syringe with medium 199 (Biowest, France) supplement with $10 \%$ fetal calf serum (Biowest, France) and $3 \%$ sodium citrate (Weifang Ensign, China). The suspension of bone marrow total nucleated cell (TNCs) was passed through the needles of different diameters $(0.9-0.4 \mathrm{~mm})$, followed by filtration through a nylon filter with a pore diameter of $100 \mu \mathrm{m}$ (Falkon, USA). The number of cells in the suspension was counted in a Goryaev chamber, and the number of cells per femur was determined.

The number of hematopoietic stem cells in BM was evaluated with a flow cytometer FACS Calibur (Becton Dickinson, USA) using monoclonal antibodies PE Rat anti-Mouse CD34 Clone RAM34 (cat. № 551387) and FITC Rat Anti-Mouse CD38 Clone 90/CD38 (BD Biosciences, USA). Samples with the addition of non-immune labeled FITC or PE antibodies of the same isotypes (cat. №553929 and №553930, clone R35-95, BD Biosciences, USA) were used as controls. The percentage of CD34+CD38 cells in the sample was determined versus to the isotype control. The analysis of the results was performed using the WinMDi 2.9 software.

To obtain the suspension of hepatocytes, the liver was minced with scissors and homogenized in a Potter homogenizer in Hanks solution at $0-2{ }^{\circ} \mathrm{C}$, followed by filtration through a nylon filter with a pore diameter of $100 \mu \mathrm{m}$ (Falkon, USA). For biochemical tests, the supernatant of the 


\begin{tabular}{|c|c|c|c|c|c|c|}
\hline \multirow{2}{*}{ GROUP } & \multirow{2}{*}{ THE DOSE OF INJECTED SUBSTANCE } & \multicolumn{5}{|c|}{ ORGAN MASS INDEX, \% } \\
\hline & & SPLEEN & LYMPH NODES & LUNGS & KIDNEY & LIVER \\
\hline Group 1 & $5.9-6.5 \mathrm{mg} / \mathrm{kg} \mathrm{NPs}$ (0.1 mL NCs) & $\begin{array}{c}0.8 \\
{[0.7 ; 0.9]}\end{array}$ & $\begin{array}{c}0.07 \\
{[0.05 ; 0.07]}\end{array}$ & $\begin{array}{c}1.1 \\
{[1.1 ; 1.2]}\end{array}$ & $\begin{array}{c}0.7 \\
{[0.6 ; 0.7]}\end{array}$ & $\begin{array}{c}6.0 \\
{[5.8 ; 6.8]}\end{array}$ \\
\hline Group 2 & $29.5-32.5 \mathrm{mg} / \mathrm{kg} \mathrm{NPs}(0.5 \mathrm{~mL})$ & $\begin{array}{c}1.2^{*} \\
{[1.0 ; 1.2]}\end{array}$ & $\begin{array}{c}0.08 \\
{[0.05 ; 0.09]}\end{array}$ & $\begin{array}{c}1.2 \\
{[1.1 ; 1.2]}\end{array}$ & $\begin{array}{c}0.6 \\
{[0.6 ; 0.7]}\end{array}$ & $\begin{array}{c}6.4 \\
{[6.3 ; 6.4]}\end{array}$ \\
\hline Group 3 & $59.1-65.0$ mg/kg NPs (1 mL) & $\begin{array}{c}1.9^{\star \#} \\
{[1.8 ; 1.9]}\end{array}$ & $\begin{array}{c}0.06 \\
{[0.05 ; 0.07]}\end{array}$ & $\begin{array}{c}1.2 \\
{[1.1 ; 1.3]}\end{array}$ & $\begin{array}{c}0.6 \\
{[0.6 ; 0.7]}\end{array}$ & $\begin{array}{c}6.2 \\
{[6.1 ; 7.1]}\end{array}$ \\
\hline Group 4 & $118.2-130.0 \mathrm{mg} / \mathrm{kg} \mathrm{NPs}(2 \mathrm{~mL})$ & $\begin{array}{c}2.1^{\star \#} \\
{[2.0 ; 2.2]}\end{array}$ & $\begin{array}{c}0.07 \\
{[0.06 ; 0.08]}\end{array}$ & $\begin{array}{c}1.3 \\
{[1.2 ; 1.3]}\end{array}$ & $\begin{array}{c}0.7 \\
{[0.6 ; 0.7]}\end{array}$ & $\begin{array}{c}6.5 \\
{[6.3 ; 6.8]}\end{array}$ \\
\hline Control 1 & $0.1 \mathrm{~mL} 5 \%$ glucose & $\begin{array}{c}0.9 \\
{[0.9 ; 1.0]}\end{array}$ & $\begin{array}{c}0.06 \\
{[0.05 ; 0.07]}\end{array}$ & $\begin{array}{c}1.2 \\
{[1.1 ; 1.2]}\end{array}$ & $\begin{array}{c}0.6 \\
{[0.6 ; 0.7]}\end{array}$ & $\begin{array}{c}5.9 \\
{[5.6 ; 6.6]}\end{array}$ \\
\hline Control 2 & $0.5 \mathrm{~mL} 5 \%$ glucose & $\begin{array}{c}1.1 \\
{[0.9 ; 1.3]}\end{array}$ & $\begin{array}{c}0.06 \\
0.05 ; 0.07]\end{array}$ & $\begin{array}{c}1.3 \\
{[1.3 ; 1.4]}\end{array}$ & $\begin{array}{c}0.7 \\
{[0.6 ; 0.7]}\end{array}$ & $\begin{array}{c}6.4 \\
{[6.4 ; 6.5]}\end{array}$ \\
\hline Control 3 & $1 \mathrm{~mL} 5 \%$ glucose & $\begin{array}{c}1.1 \\
{[1.1 ; 1.2]}\end{array}$ & $0.06[0.05 ; 0.08]$ & $\begin{array}{c}1.2 \\
{[1.1 ; 1.2]}\end{array}$ & $\begin{array}{c}0.6 \\
{[0.6 ; 0.7]}\end{array}$ & $\begin{array}{c}6.3 \\
{[6.1 ; 6.6]}\end{array}$ \\
\hline Control 4 & $2 \mathrm{~mL} 5 \%$ glucose & $\begin{array}{c}1.1 \\
{[1.0 ; 1.1]}\end{array}$ & $\begin{array}{c}0.06 \\
{[0.05 ; 0.07]}\end{array}$ & $\begin{array}{c}1.1 \\
{[1.0 ; 1.2]}\end{array}$ & $\begin{array}{c}0.6 \\
{[0.5 ; 0.6]}\end{array}$ & $\begin{array}{c}6.0 \\
{[5.8 ; 7.2]}\end{array}$ \\
\hline Intact & - & $\begin{array}{c}0.9 \\
{[0.8 ; 0.9]}\end{array}$ & $\begin{array}{c}0.06 \\
{[0.05 ; 0.08]}\end{array}$ & $\begin{array}{c}1.2 \\
{[1.2 ; 1.3]}\end{array}$ & $\begin{array}{c}0.6 \\
{[0.5 ; 0.6]}\end{array}$ & $\begin{array}{c}6.5 \\
{[6.4 ; 6.7]}\end{array}$ \\
\hline
\end{tabular}

Table 3. The weight indices of the organs of mice on the $14^{\text {th }}$ day after the induction of acute toxicity by the injection of different concentrations of NPs in nanocomplexes, Me $\left[25 ; 75^{\text {th }}\right.$ percentiles]. Notes: * $-p<0.005$ compared to intact animals; \# - compared to control of the corresponding group; according to the Bonferroni-corrected Mann-Whitney U-test.

liver homogenate was obtained by centrifugation (5 min, 1,500 rpm). The content of total protein in the supernatant of the liver homogenate was measured using test kits "Total protein" (Randox, UK). Optical density measurements were performed on a biochemical analyzer Chem 7 (ERBA Diagnostics Mannheim, Germany) at a wavelength of $540 \mathrm{~nm}$. The amount of protein was calculated according to the instructions of the manufacturer.

To determine the activity of the enzymes gamma-glutamyltransferase (GGT) and glucose-6-phosphate dehydrogenase (G6PD) in the supernatant of liver homogenates, test sets of reagents " $\gamma$-GT (GGT)" and "G6PDH" (Randox, UK) were used. Optical density measurements were performed with a biochemical analyzer Chem 7 (ERBA Diagnostics Mannheim, Germany) at a wavelength of $365 \mathrm{~nm}$. The calculation of enzyme activity was performed according to the manufacturer's instructions and normalized to $1 \mathrm{mg}$ of protein.

The spleen, liver, and kidneys were isolated from mice for histological examination. Tissue fragments were fixed in $10 \%$ neutral formalin solution, dehydrated with ethanol and ethanol-ether mixture (1:1) and paraffin sections with a thickness of $7-9 \mu \mathrm{m}$ were prepared. The sections were stained with hematoxylin-eosin. The obtained histological specimens were studied by a Primo Star light microscope (Carl Zeiss, Germany) and photographed using a camera Axiocam 105 (Carl Zeiss, Germany).

The data were presented as medians with lower and upper quartiles (Me [LQ; UQ]) according to the $\mathrm{Cl}$ and analyzed by non-parametric statistics using the Statistica 10.0 software (StatSoft, Inc., USA). Multiple comparisons of independent samples were performed by the Kruskal-Wallis one-way analysis (differences were considered significant at $p<0.05$ ). Pairwise comparison of groups was performed using nonparametric Bonferroni-corrected Mann-Whitney U test (differences were considered significant at $p<0.005)$.

\section{RESULTS AND DISCUSSION}

It was found that with a single intra-abdominal injection of NCs solution into the mice of 1-3 experimental groups, no fatalities were registered among the animals (Table 1). During the experiment, no animal death was observed in the appropriate control groups with the administration of $5 \%$ glucose solution. Daily examination did not reveal any symptoms of animal intoxication in any of the above groups throughout the observation period. There were no differences in the general condition and behavior of animals, feed and water consumption between 1-3 experimental groups.

Intra-abdominal injection of $2 \mathrm{~mL}$ sterile NCs with the concentration of NPs as the active substance $118.2-130.0 \mathrm{mg} / \mathrm{kg}$ body weight of animals (group 4) caused the symptoms of intoxication in mice, which increased during the first day of observation and reached the maximum on the third day. There were found ataxia, adynamia, tremor of the whole body, tousled fur, decreased food and water consumption. In addition, the death of $50 \%$ of the animals was found in this group by the third day of the experiment. Subsequently, intoxication gradually disappeared and normal activity of the surviving animals was restored. However, no more than $20 \%$ of animals survived till the $14^{\text {th }}$ day (Table 1 ). In the corresponding control group, we stated the death of $10 \%$ mice on the third day. No changes in behavior were observed in the surviving animals.

Thus, the injection of NCs solutions in the mice of the experimental groups 1-3 did not lead to the intoxication by integral parameters of the general condition of the experimental animals. The only exception was group 4, which animals showed an increase in the signs of intoxication throughout the observation period, which led to the death of $80 \%$ of mice on the $10^{\text {th }}$ day after the injection of NCs (Table 1).

As can be seen from Table 2, under the conditions of acute toxicity on the $14^{\text {th }}$ day after the injection of NCs in animals of 1-3 experimental groups, weight gain was $1.1[0.8 ; 1,2] ; 1.3[1.3 ; 1.5]$ and $0.1[0.1 ; 0.1] \mathrm{g}$, respectively, while in intact animals this figure was 2.0 [1.8; 2.2]. The weight gain of group 4 mice had negative dynamics and was significantly reduced in comparison with both intact animals and animals of the corresponding control group. In all control groups, with the administration of appropriate volumes of $5 \%$ glucose solution, only the positive increase in body weight of the animals was observed throughout the observation period (Table 2).

Macroscopic examination of the organs of animals of all experimental groups revealed no changes in their location in the abdominal cavity. In 


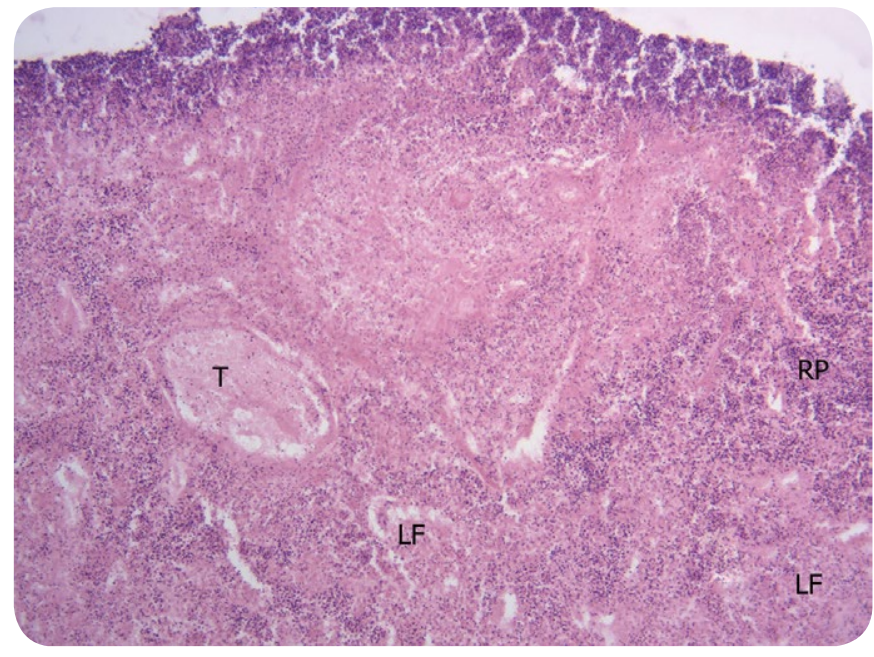

A Fig. 1. The micrograph of a histological section of the spleen with a solid tumor of a group 4 mice with the injection of $2 \mathrm{~mL}$ NCs (NPs concentration $118.2-130 \mathrm{mg} / \mathrm{kg}$ ), the $14^{\text {th }}$ day of the study; hematoxylin-eosin staining, $x 400$. Notes: $R P$ - red pulp; $T$ - tumor; LF - lymphoid follicles.

Kruskal-Wallis test: $\mathrm{H}=\mathbf{1 2 . 5} \mathrm{p}=\mathbf{0 . 1}$

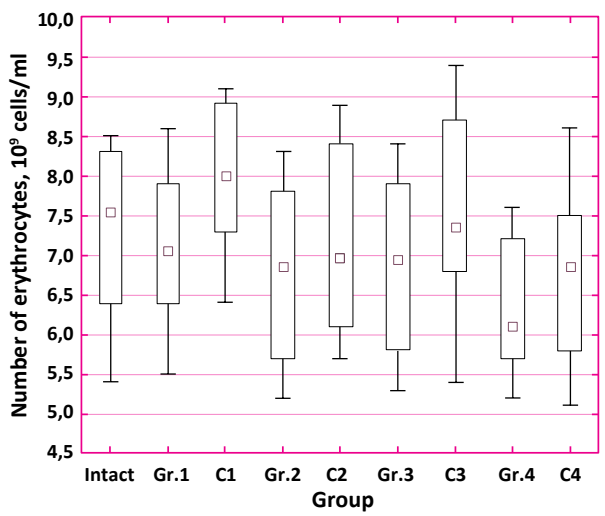

$\square$ Median

I Min.-Max the subcutaneous tissue there was a moderate deposition of fat, the peritoneum was transparent, smooth, without hemorrhage. No unusual contents were found in the abdominal cavity. The spleen was elastic, reddishbrown, the section shows fine-grained tissue. Inguinal lymph nodes had soft-elastic consistency, normal size, bean-shaped elongated form with a smooth surface and not fused with the surrounding tissues. All the lobes were well distinguished in the liver, its capsule was not tense, the surface of the organ was smooth without nodules, and the parenchyma is of equal red-brown colour in the section site. Kidneys were with a capsule, which was easily removed. In the section site they were dark red, dense, with preserved pattern of layers. Macroscopic examination of the thoracic cavity showed that all animals had no changes in lungs. They filled the entire pleural cavity, retained elasticity, without adhesions between the pleura, the walls of the bronchi were not thickened, and there were no foci of hemorrhage.

However, in one of the $20 \%$ of the surviving animals in group 4 , a significant solid tumor was found on the spleen. Microscopic examination of the spleen revealed a number of disorders of its architectonics: aplasia of lymphoid follicles, increase in the relative area of red pulp compared to white, infiltration by lymphoblasts and lymphocytes (small, medium and large). There were foci of plasma cells between the sinuses of the pulpal cords (Fig. 1). Decreased proliferation and differentiation of lymphoid cells was observed, which was accompanied by the atrophy of lymphoid follicles. Macro- and microscopic analysis of other organs of animals in

Fig. 2. The content of erythrocytes (A) and leukocytes (B) in the peripheral blood of animals after the injection of different concentrations of NPS in nanocomplexes.

Notes: ${ }^{*}-p<0.005$ compared to intact group; according to the Bonferroni-corrected Mann-Whitney U-test.
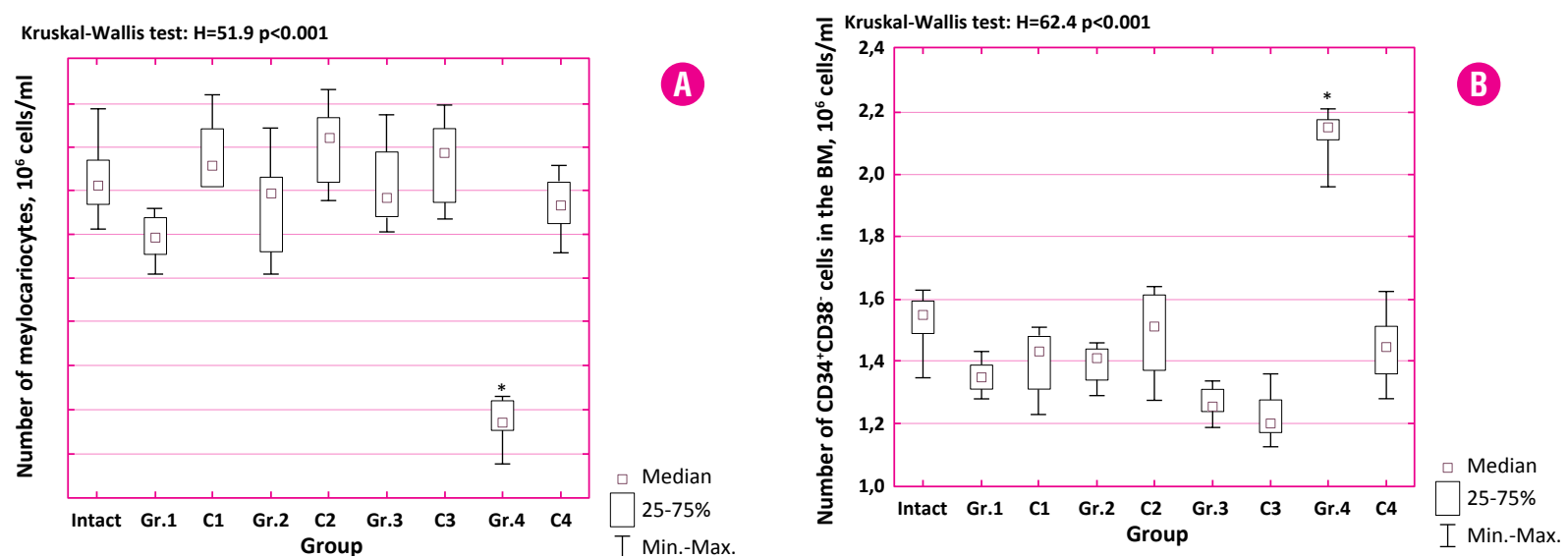

Fig. 3. The number of TNCS (A) and CD34+CD38- cells (B) in the bone marrow of animals after the injection of different concentrations of NPS in nanocomplexes.

Notes: ${ }^{*}-p<0.005$ compared with intact animals; according to the Bonferroni-corrected Mann-Whitney U-test. 

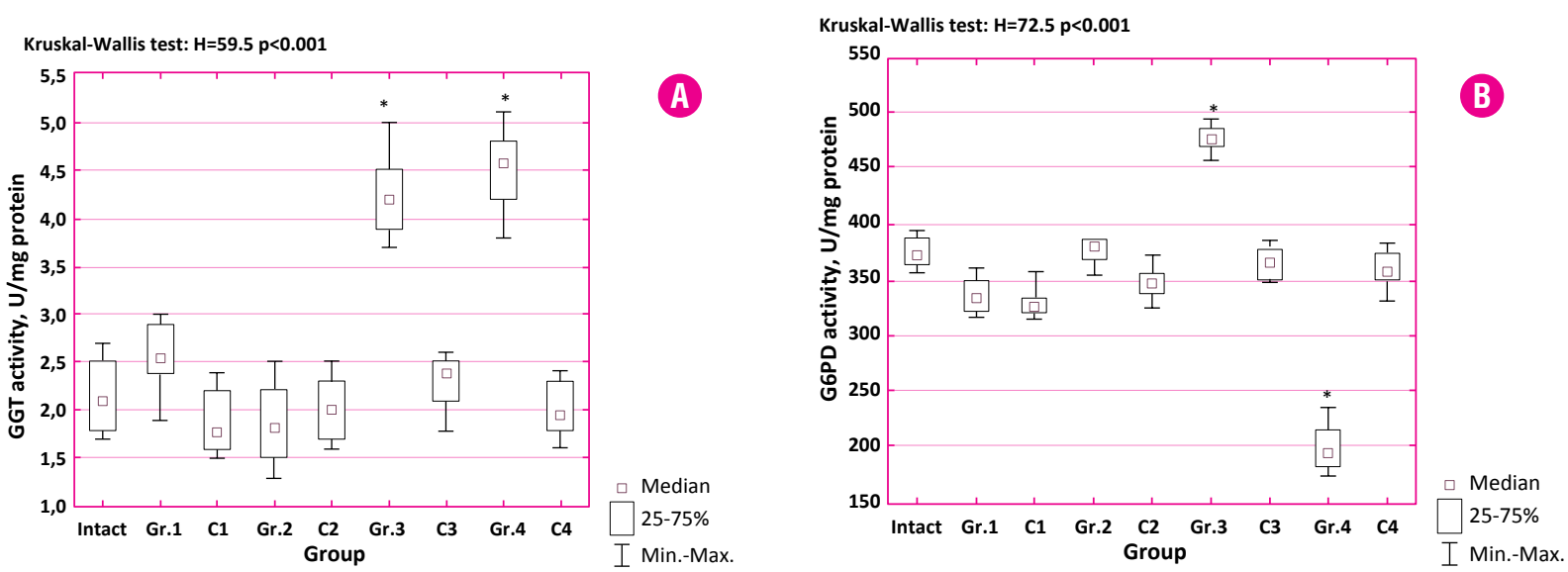

Fig. 4. The activity of gamma-glutamyltransferase (A) and glucose-6-phosphate dehydrogenase (B) in the liver of animals after the injection of different concentrations of NPS in nanocomplexes.

Notes: ${ }^{*}-p<0.005$ compared to intact animals; according to the Bonferroni-corrected Mann-Whitney U-test.

this group showed that they did not differ in structure from similar parameters of mice in the corresponding control group.

In the animals of all experimental groups, no significant differences were found between the indices of mass of the lungs, kidneys, liver and lymph nodes, respectively, as in intact animals and groups with the administration of $5 \%$ glucose solution (Table 3 ). Spleen mass indices did not significantly differed from similar controls only in animals of groups 1 and 2 . In the animals of groups 2-4, a dose-dependent increase in this parameter was observed in accordance with intact control. The obtained data on the increase of spleen mass indices are consistent with the data of Belkina I. et al. [28], who found a similar increase in the index of this organ mass when NPs of gadolinium orthovanadate at a dose of $0.33 \mathrm{mg} / \mathrm{kg}$ body weight of experimental animals were administered per os.

The analysis of animal peripheral blood is one of the most common and important laboratory tests, which reflects the processes occurring in the organism in response to various factors, including the ones after the use of nanomaterials. When determining the parameters of peripheral blood of animals of all experimental groups on the $14^{\text {th }}$ day of the study no significant difference in the number erythrocytes compared with intact control was found (Fig. 2). Regarding the number of leukocytes in the peripheral blood of experimental animals of groups 1-3, no significant changes were revealed, excluding group 4, where a significant increase of leukocytes count was found in comparison with the corresponding control and intact animals. This may indicate the manifestation of the protective properties of the organism in response to the administration of a potentially toxic substance in the highest concentrations.

The next step in the study of NCs acute toxicity was to determine their effect on the hematopoietic system, namely the number of bone marrow total nucleated cell (TNCs) and hematopoietic stem cells (HSCs) with the phenotype $\mathrm{CD} 34^{+} \mathrm{CD} 38^{-}$in the bone marrow. Intraperitoneal administration of NCs to the animals of 1-3 experimental groups did not lead to significant changes in the number of bone marrow TNCs and HSCs in the bone marrow (Fig. 3). At the same time, in the animals of group 4 with the administration of the maximum dose of NPs in nanocomplexes there was a significant decrease in the number of bone marrow TNCs and an increase in the content of $\mathrm{CD} 34^{+} \mathrm{CD} 38^{-}$cells in the bone marrow. A significant change in the total number of bone marrow TNCs and HSCs among them in the animals of this group is due to the influence of NCs, that is confirmed by the fact that there are no changes in similar parameters with the injection of $5 \%$ glucose solutions.

A comprehensive approach to the analysis of the effects of NCs as a potentially toxic substance requires the study of marker biochemical parameters. The main markers of toxic effects of compounds are parameters that characterize the liver functions. A number of enzymes can act as such parameters, allowing to estimate the efficiency and the basic detoxifying functions of a liver. The most noticeable role in the system of antioxidant protection of biological molecules in the aqueous phase is played by glutathione, which neutralizes free radicals and prevents their formation [29]. The main enzyme of glutathione catabolism is gammaglutamyltransferase (GGT), which catalyzes the transfer of the gammaglutamyl group from gamma-glutamyl peptide to amino acid or other peptide and thus participates in the transport of this amino acid across the cell membrane. The enzyme GGT is of great clinical importance in the diagnosis of various pathological conditions, because the increase in its concentration indicates either the destruction of cell membranes, or the induction of microsomal oxidation under the influence of toxic agents.

Under the conditions of acute toxicity induction, the injection of NCs in the animals of groups 3 and 4 almost doubled the activity of GGT compared with a similar rate of intact animals (Fig. 4). This fact indicates a significant activation of metabolic processes at the cellular level, namely the development of oxidative stress. The maximum values of the content of this enzyme were observed in group 4 with the administration of NCs (NPs concentration of $118.2-130.0 \mathrm{mg} / \mathrm{kg}$ ) compared with both the intact control and the corresponding control group with the administration of 5 $\%$ glucose solution.

A sharp increase in GGT in the animals of groups 3 and 4 was accompanied by significant pathomorphological changes in the structure of the liver (Figs. 5, 6). The intensity of such microstructural reorganization directly depended on the dose of injected NPs in nanocomplexes. Thus, in the animals of group 3, dilation of the portal vein, accumulation of lymphoid cells around it, fatty dystrophy of some cells were observed (Fig. 5). The presence of lymphoid nodules was noted, each one consisted of a complex of lymphoid cells: lymphocytes, lymphoblasts, macrophages and plasma cells.

In the mice of group 4, which received NCs with a maximal concentration NPs (118.2-130.0 mg/kg), the dystrophic changes of hepatocytes in the central parts of the liver and residual dystrophic phenomena in small areas of the liver lobe were found (Fig. 6). The number of hepatocytes with multiple nucleoli, polyploid and hyperchromic nuclei increased. Focal areas with signs of necrosis and large areas with granular, small-droplet and small-vacuolar hepatocyte dystrophy were found in the animals of this group. The maximum concentration of NPs (118.2-130.0 mg/kg) in the animals of group 4, on the one hand, locally enhanced necrosis and dystrophy in the liver, and, on the other hand, led to an increase in the area of islets of active hepatocyte proliferation with large, often polyploid nuclei, which indicates tissue regeneration (Fig. 6).

In general, the analysis of the liver structural organization on the $14^{\text {th }}$ day after the intraperitoneal injection of NCs with a concentration of NPS 


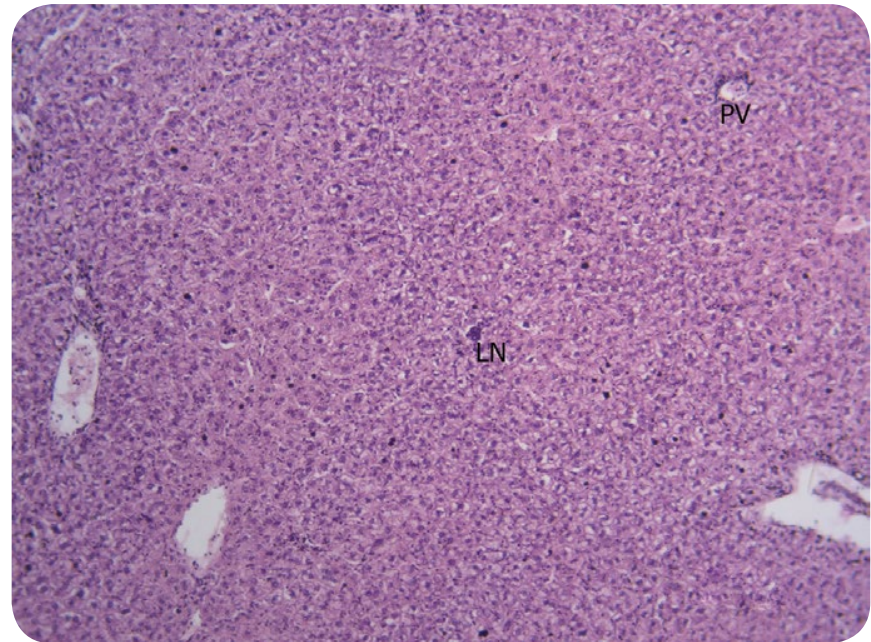

A Fig. 5 Photomicrograph of the histological section of the murine liver of the group 3 with the injection of $1 \mathrm{~mL}$ NCs (NPs concentration $59.1-65.0 \mathrm{mg} / \mathrm{kg}$ ), the $14^{\text {th }}$ day of the study; hematoxylin-eosin staining; $x 100$. Notes: LN - lymphoid nodules; PV - portal vein.

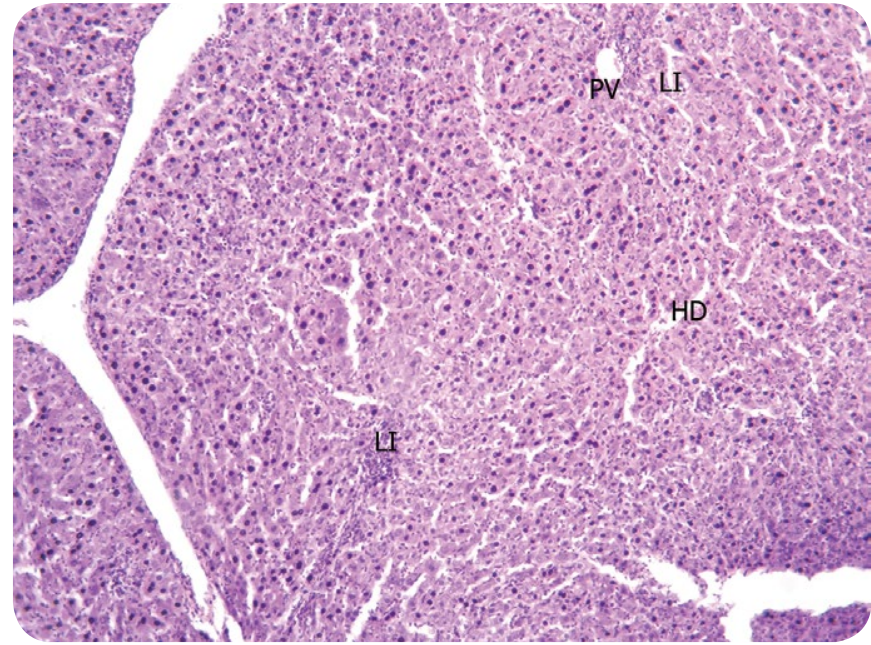

- Fig. 6. The micrograph of the histological section of the liver of a group 4 mouse with the injection of $2 \mathrm{~mL}$ NCs (NPs concentration $118.2-130 \mathrm{mg} / \mathrm{kg}$ ), the $14^{\text {th }}$ day of the study hematoxylin-eosin staining; $x 100$ Notes: PV - portal vein; LI - lymphoid infiltration; HD - hepatic ducts.

ticles as an active substance of NCs are the basis for the possibility of their use as a promising compound for the creation of innovative tools for the treatment of various pathologies.

Belkina I. et al. studied the toxicity, the dynamics of accumulation and the excretion time of gadolinium orthovanadate in vivo. They found that their oral and intraperitoneal administration to healthy rats did not lead to the death of animals and changes in the mass indices of organs. The authors did not show toxicity to organs (except for an increase in the mass of the spleen and tibialis anterior muscle) when gadolinium orthovanadate NPs were administered orally for 30 days to adult male rats. Oral administration of gadolinium orthovanadate NPs for 70 days to male rats only resulted in increased ventral prostate mass and decreased testicular alanine aminotransferase (ALT) activity at the highest NP dose $(3.0 \mathrm{mg} / \mathrm{kg})$. There were no negative effects on the reproductive system testosterone levels, as well as any other changes in the studied biochemical parameters. Complete elimination of NPs from the body occurred 30 days after their administration [31].

In another study, in rats with age-related and neonatally determined pathology of sexual function under the influence of oral administration of gadolinium orthovanadate NPs at a dose of $0.33 \mathrm{mg} / \mathrm{kg}$ for 70 days showed the normalization of spermatogenesis, testosterone levels, triglycerides, total cholesterol, serum arginine, alanine aminotransferase activity in the liver of animals, their fertility and reproduction, reduction of embryonic mortality, that generally contributed to the normalization of reproductive potential of males [28, 32].

Gadolinium orthovanadate NPs are able to act as geroprotectors. The use of NPs of $\mathrm{GdYVO}_{4}: \mathrm{Eu}^{3+}$ with water $(0.25-0.3 \mathrm{mg} / \mathrm{kg}$ body weight per day) from 22 month age to the end of life leads to a significant increase in rat survival [33]. The chronic use (up to 50 days) of gadolinium orthovanadate NPs activated by europium slowed the age-related increase in the body weight and the development of hyperglycemia compared to baseline in male rats aged 18-21 months [34]. Even longer (within 70 days) consumption by old male rats of colloidal solution of NPs of gadolinium orthovanadate $\mathrm{GdYVO}_{4}: \mathrm{Eu}^{3+}$ led to an increase in testosterone concentration, activation of spermatogenesis, increased antioxidant activity of mature sperm, the reduction of induced chemiluminescence of epididymal sperm suspension in the Fenton's reaction [34].

The proven absence of toxic effects of NCs on the body of healthy animals when using NPs, as the active substance of nanocomplexes in doses less than $118.2 \mathrm{mg} / \mathrm{kg}$, indicates the safety of their use in the treat- 
ment of experimental oncopathologies, including Ehrlich adenocarcinoma (EAC) $[24,35]$. Goltsev A. et al. proved that the treatment of EAC cells with nanocomplexes containing $1.3 \mathrm{~g} / \mathrm{L}$ of spherical NPs and cholesterol $(0.55 \mathrm{~g} / \mathrm{L})$ provided the maximum antitumor effect, due to $70 \%$ inhibition of EAC growth in vivo, and inhibition did not exceed $51 \%$ when using NPs only in the same concentration. [24, 35]. Thus, the data obtained in this study confirm that the administration of a conditional therapeutic dose of used NCs did not have a toxic effect on the function of normal cells of the body.

The median lethal dose of NPs in nanocomplexes, which causes the death of $50 \%$ animals of group 4 with intra-abdominal injection is determined as $2 \mathrm{~mL} \mathrm{NCs} \mathrm{(NPs} \mathrm{concentration} 118.2-130.0 \mathrm{mg} / \mathrm{kg}$ ). This $L D_{50}$ is
20 times higher than therapeutic dose $(5.9-6.5 \mathrm{mg} / \mathrm{kg})$. The administration of NCs with a concentration of NPs $118.2-130.0 \mathrm{mg} / \mathrm{kg}$ caused a decrease in the number of bone marrow TNCs against the background of increased hematopoietic stem cells with phenotype CD34+CD38-, necrotic and dystrophic changes in the liver, and decreased activity of the G6PD enzyme. In addition, one in $20 \%$ of the surviving animals was found to have a tumor in the spleen, likely indicating tumorigenic activity of NCs when used in large doses.

Thus, according to the toxicological classification [26] NCs containing spherical orthovanadate NPs composition $\mathrm{GdYVO}_{4}: \mathrm{Eu}^{3+}$ and cholesterol, the parameter of $\mathrm{LD}_{50}$ and under intra-abdominal injection can be classified as toxicity class IV.

\section{CONCLUSION}

1. In the model of acute toxicity in mice, there was determined the potential median lethal dose of nanocomplexes containing gadolinium orthovanadate nanoparticles at concentration $118.2-130.0 \mathrm{mg} / \mathrm{kg}$, which caused the death of $50 \%$ of mice in the experimental group.

2. According to the $L D_{50}$, nanocomplexes can be classified as low-toxic substances. This determines the prospects of their use to create nanostructured forms of medicines.

The study was carried out within the program of the National Academy of Sciences of Ukraine «Support for the development of priority areas of research» (code 6541230), agreement № 2.2.6.130.

\section{REFERENCES:}

1. Chekman I. S. Fiziologichni ta farmakologichni vlastyvosti nanorozmirnyh struktur. [Physiological and pharmacological properties of nanosized structures]. Fiziologichnyj zhurnal - Physiological journal. 2015; 61(6):129138. [In Ukrainian]

2. Leonenko NS, Demetskaya OV, Leonenko OB. Osoblyvosti fizyko-himichnyh vlastyvostej ta toksychnoi' dii' nanomaterialiv - do problemy ocinky i'hn'ogo nebezpechnogo vplyvu na zhyvi organizmy (ogljad literatury) [Features of physicochemical properties and toxic effects of nanomaterials - to the problem of assessing their dangerous effects on living organisms (review)]. Suchasni problemy toksykologii', harchovoi' ta himichnoi' bezpeky - Modern problems of toxicology, food and chemical safety. 2016; 1:64-76. [In Ukrainian]

3. Poole Ch, Owens F. Nanotehnologyy. 2-e, dopolnennoe yzdanye. Moskva: Tehnosfera [Nanotechnology. $2^{\text {nd }}$, revised edition. Moscow: Technosphere]. 2006. 424 p. [In Russian]

4. Checkman IS. Nanochastynky: vlastyvosti ta perspektyvy zastosuvannja [Nanoparticles: properties and application prospects]. Ukrai'ns'kyj biohimichnyj zhurnal Ukrainian Biochemical Journal. 2009; 81(1):122-129. [In Ukrainian]

5. Klochkov VK, Kavok NS, Malyukin YuV, Seminozhenko VP. Эffekt specyfycheskogo vzaymodejstvyja nanokrystallov GdYVO $\mathrm{O}_{4}$ Eu^3+ $\mathrm{S}$ jadramy kletok [Effect of specific interaction of GdYVO 4 : Eu^ 3 + nanocrystals with cell nuclei]. Dopovidi NAN Ukrai'ny - Reports of the National Academy of Sciences of Ukraine. 2010; 10:81-86. [In Russian]

6. Donaldson K, Stone V. Current hypotheses on the mechanisms of toxicity of ultrafine particles. Ann Ist Super Sanita. 2003; 39(3):405-410.

7. Kavok NS, Averchenko KA, Klochkov VK, et al. Mitochondrial potential changes in single rat hepatocytes: The effect of orthovanadate nanoparticles doped with rare-earth elements. Eur Phys J Plus. 2014; 371(12):127-130.

8. Escudero A, Becerro Al, Carrillo-Carrion C, et al. Rare earth based nanostructured materials: Synthesis, functionalization, properties and bioimaging and biosensing applications. Nanophotonics. 2017; 6(5):881-921.

9. Goltsev AM, Malyukin YV, Babenko NM, et al. Antitumor activity of spherical nanoparticles GdYVO4:Eu3+ depends on pre-incubation time. Appl. Nanosci. 2020; 10(8):2749-2758.

10. Rehder $D$. The potentiality of vanadium in medicinal applications. Future Med Chem. 2012; 4(14):1823-1837.

11. Sakurai H, Yoshikawa Y, Yasui H. Current state for the development of metallopharmaceutics and anti-diabetic metal complexes. Chem Soc Rev. 2008 . 37, № 11. P. 2383-2392.

12. Mehdi MZ, Pandey SK, Théberge JF, Srivastava AK. Insulin signal mimicry as a mechanism for the insulin-like eff ects of vanadium. Cell Biochem Biophys. 2006; 44(1):73-81.

13. Treviño S, Díaz A, Sánchez-Lara E, et al. Vanadium in Biological Action: Chemical, Pharmacological Aspects, and Metabolic Implications in Diabetes Mellitus. Biol Trace Elem Res. 2019; 188:68-98.

14. Fu PP, Xia Q, Hwang HM, et al. Mechanisms of nanotoxicity: Generation of reactive oxygen species. J Food Drug Anal. 2014; 22(1):64-75.

15. Köpf-Maier $P$, Köpf $H$. Metallocene complexes: organometallic antitumor agents. Drugs Future. 1986; 11:297-319.

16. Köpf-Maier $P, K$ Kahl $D$. Tumor inhibition by metallocenes: ultrastructural localization of titanium and vanadium in treated tumor cells by electron energy loss spectroscopy. Chem-Biol Interact. 1983; 44(3):317-328.

17. Köpf-Maier P, Wagner W, Liss E. Cytokinetic behavior of Ehrlich ascites tumor after in vivo treatment with cis - diamminedichloroplatinum(II) and metallocene dichlorides. J Cancer Res Clin Oncol. 1981; 102(1):21-30.

18. Köpf-Maier P. Development of necroses virus, activation and giant cell formation after treatment of Ehrlich ascites tumor with metallocene dichlorides. $\mathrm{J}$ Cancer Res Clin Oncol. 1982; 103:145-164. 
19. Rodriguez-Mercado JJ, Mateos-Nava RA, Altamirano-Lozano MA. DNA damage induction in human cells exposed to vanadium oxides in vitro. Toxicol In Vitro. 2011; 25(8):1996-2002.

20. Molinuevo MS, Barrio DA, Cortizo AM, Etcheverry SB. Antitumoral properties of two new vanadyl (IV) complexes in osteoblasts in culture: role of apoptosis and oxidative stress. Cancer Chemother Pharmacol. 2004; 53(2):163-172.

21. Korbecki J, Baranowska-Bosiacka I, Gutowska I, Chlubek D. Biochemical and medical importance of vanadium compounds. Acta Biochimica Polonica. 2012; 59(2):195-200.

22. Klochkov VK. Instytut scyntyljacijnyh materialiv NAN Ukrai'ny, vlasnyk. Sposib otrymannja vodnoi' dyspersii' holesterynu [Institute of Scintillation Materials of the National Academy of Sciences of Ukraine, owner. The method of obtaining an aqueous dispersion of cholesterol]. Patent Ukrai'ny - Patent of Ukraine 10801. 10.03.2015. [In Ukrainian]

23. Al - Jarallah A, Trigatti BL. A role for the scavenger receptor, class B type I in high density lipoprotein dependent activation of cellular signaling pathways. Biochim Biophys Acta. 2010; 1801(1):1239-1248.

24. Goltsev AN, Babenko NN, Gaevskaya YA, et al. Nanotechniques inactivate cancer stem cells. Nanoscale Res Let. 2017; 12(1):415.

25. Rukovodstvo po eksperimental'nomu (doklinicheskomu) izucheniyu novykh farmakologicheskikh veshchestv / pod obshchey red. Khabrieva RU. [Guidelines for experimental (preclinical) study of new pharmacological substances / ed. Khabrieva RU.]. Moskva: OAO Izdatel'stvo «Meditsina» - Moscow: JSC Publishing House «Medicine». 2005. 832 p. [In Russian]

26. Doklinichni doslidzhennja likars'kyh zasobiv (metodychni rekomendacii') / za red. OV Stefanova [Preclinical studies of drugs (guidelines) / ed. Stefanova OB.] Kyi'v: Avicena - Kyiv: Avicenna. 2001. 528 p. [In Ukrainian]

27. Laboratorni metody doslidzhen' u biologii', tvarynnyctvi ta veterynarnij medycyni: Dovidnyk / za red. Vlizla VV. [Laboratory research methods in biology, animal husbandry and veterinary medicine: Handbook / ed. Vlizla VV]. L'viv: Spolom -Lviv: Spolom. 2012. 764 p. [In Ukrainian]

28. Belkina 10, Karpenko NA, Koreneva EM, et al. Korrektsiya rasstroystv reproduktivnoy funktsii samtsov krys s pomoshch'yu nanochastits ortovanadata gadoliniya [Correction of reproductive disorders in male rats using nanoparticles of gadolinium orthovanadate]. Vesci Nacyjanal»naj akadjemii navuk Belaruci. Seryja medycynskih navuk - Bulletin of the National Academy of Sciences of Belarus. Medical Sciences Series.2018; 15(3):293-305. [In Russian]

29. Kulinskiy VI, Kolesnichenko LS. Sistema glutationa. II. Drugie fermenty, tiol-disul'fidnyy obmen, vospalenie i immunitet, funktsii [Glutathione system. II. Other enzymes, thiol-disulfide metabolism, inflammation and immunity, functions]. Biomedical Chemistry - Biomeditsinskaya khimiya. 2009; 55(4):365-379. [In Russian]

30. Stanton RC. Glucose-6-Phosphate Dehydrogenase, NADPH, and Cell Survival. IUBMB. 2012; 64(5):362-369.

31. Belkina 10. Gonadotoksychnist' nanochastynok gadoliniju ortovanadatu za umov hronichnogo nadhodzhennja [Gonadotoxicity of gadolinium orthovanadate nanoparticles under conditions of chronic intake]. Problemy endokrynnoi' patologii' - Problems of endocrine pathology. 2017; 3:78-85. [In Ukrainian]

32. Koreneva EM, Karpenko NO, Smolenko NP. Vplyv nanochastynok ortovanadatu g'adoliniju ta dioksydu ceriju na spermogramu doroslyh samciv shhuriv iz neonatal'no indukovanymy rozladamy reproduktyvnoi' funkcii' [Influence of gadolinium orthovanadate nanoparticles and cerium dioxide on the spermogram of adult male rats with neonatally induced disorders of reproductive function]. Problemy endokrynnoi' patologii' - Problems of endocrine pathology. 2016; 1:48-55. [In Ukrainian]

33. Nikitchenko YuV, Klochkov VK, Kavok NS, et al. Nanochastitsy ortovanadata gadoliniya uvelichivayut vyzhivaemost' starykh krys [Nanoparticles of gadolinium orthovanadate increase the survival rate of old rats]. Dopovidi NAN Ukrai'ny - Reports of the National Academy of Sciences of Ukraine. 2020; 2:29-36. [In Russian]

34. Karpenko NO, Korenieva YeM, Chystiakova Eye, et al. The influence of the rare-earth metals nanoparticles on the rat's males reproductive function in the descending stage of ontogenesis. Ukr biopharm j. 2016; 45(4):75-80.

35. Goltsev AN, Babenko NN, Gaevskaya YuA, et al. Application of nanoparticles based on rare earth orthovanadates to inactivate Ehrlich carcinoma growth. Biotechnol Acta. 2015; 8(4):113-121.

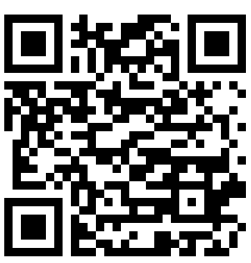




\title{
Оцінка токсичності нанокомплексів, що містять наночастинки ортованадату гадолінія і холестерин
}

\author{
Гольцев А. М. ${ }^{1}$, Бондарович М. О. ${ }^{1}$, Бабенко Н. М. ${ }^{1}$, Гаєвська Ю. О. ${ }^{1}$ Останкова Л. В. ${ }^{1}$, \\ Останков М. В. ${ }^{1}$, Волкова Н. О ${ }^{1}$, Клочков В. К. ${ }^{2}$ \\ ${ }^{1}$ Інститут проблем кріобіологї та кріомедицини НАН України, Харків, Украӥна, \\ ${ }^{2}$ Інститут сиинтиляційних матеріалів НАН Украӥни, Харків, Украӥна
}

\section{PEЗЮME}

Синтезові в Інституті сцинтиляційних матеріалів НАН України нанокомплекси (НК), що складаються з наночастинок (НЧ) ортованадату гадолінія і холестерину, $є$ перспективними сполуками, які можуть бути застосовані як зонди і люмінесцентні мітки для пухлинних клітин або засобів лікування експериментальної онкопатології. Однак нез'ясованим залишається питання біобезпеки таких речовин.

МЕТА РОБотИ - оцінити гострий токсичний вплив нанокомплексів на організм здорових мишей.

МАТЕРІАЛИ ТА МЕТоДИ. НК, які містять наночастинки GdYVO 4 :ЕUЗ+ та холестерин на 5 \% глюкозі, вводили мишам ВАLB/C одноразово внутрішньочеревно в об'ємах 0,1 мл, 0,5 мл, 1 мл, 2 мл, що відповідає 5,9-6,5 мг, 29,5-32,5 мг, 59,1-65,0 мг, 118,2-130,0 мг НЧ на 1 кг маси. Контрольним тваринам вводили розчин 5 \% глюкози в тих же об'ємах. На 14 добу визначали морфологічні характеристики внутрішніх органів, кількість CD34+CD38- клітин серед мієлокаріоцитів, активність ү-глутаміл-трансфрерази (ГГT) $і$ ү-глюкоза-6-сроссрат дегідрогенази (Г-6-ФДГ) в гомогенатах печінки.

РЕЗУЛЬТАТИ. При введенні НК в дозі менш ніж 118,2 мг/кг маси тіла, не було зафріксовано летальних випадків і симптомів інтоксикації, однак виявлено дозозалежне збільшення вмісту ГГТ в печінці піддослідних тварин. Застосування НК в дозі 118,2-130,0 мг/кг маси на 3-тю добу призвело до загибелі 50 \% тварин. В цій групі на 14-у добу виявлено новоутворення у селезінці однієї з тварин, що вижили, зниження кількості мієлокаріоцитів на тлі підвищення вмісту гемопоетичних стовбурових клітин з фенотипом CD34+CD38-, некротичні та дистрофрічні зміни в печінці, а також зниження активності ферменту Г-6-ФДГ.

Висновки. Визначена потенційна напівлетальна доза наночастинок ортованадату гадолінія і холестерину в складі нанокомплексів, яка становила 118,2-130,0 мг на 1 кг маси тварини, що дозволяє віднести їх до малотоксичних речовин.

КлючовІ словА: наночастинки; нанокомплекси; ортованадат гадолінію; напівлетальна доза 